\title{
First record of the Emperor angelfish, Pomacanthus imperator (Acthenoptergii: Pomacanthidae) in the Syrian coast (Eastern Mediterranean)
}

\author{
Adib Saad ${ }^{1 *}$ (D) Hasan Alkusairy ${ }^{1}$ and Waad Sabour ${ }^{2}$
}

\begin{abstract}
This paper reports the first record of the Emperor angelfish Pomacanthus imperator (Bloch, 1787) from the Syrian coast. The specimen was caught by trap at depth of $15 \mathrm{~m}$ on 18 February 2018. The fish measured $272 \mathrm{~mm}$ in total length, and weighted $1349 \mathrm{~g}$ The record represents the second sighting of this species in the Levantine basin, but since it is based on a single isolated individual there is no evidence that the species has established a population in Syrian waters. Therefore at present $P$. imperator must be regarded as a casual species.
\end{abstract}

Keywords: Pomacanthus imperator, First record, Non-indigenous, Biological invasions, Syria

\section{Background}

The Family: Pomacanthidae constitutes of marine tropical and subtropical Atlantic and Indo-Pacific fish species commonly known as angelfishes. This family is composed of about 82 different species characterized by a strong spine at the angle of the preopercle and striking colour patterns (Nelson 2006).

To date, the Mediterranean Sea has been subjected to numerous non-indigenous species, introductions raising the attention of scientists, managers, and media. Several introduction pathways contribute to these introduction, including Lessepsian invasion. The opening of the Suez Canal in 1869 connecting the Red Sea with the Mediterranean Sea enabled many tropical organisms originating in the Red Sea to invade and colonize the Mediterranean. The influx of Red Sea biota into the Mediterranean, termed Lessepsian invasion, encompasses many taxa (Por 1978; Gerovasileiou et al. 2016). Concerning fish, Saad (2005) presented a list of Lessepsian fish species in Syrian marine waters. at that time no species belonging to the family pomacantidae was recorded or documented. Golani (2010)

\footnotetext{
* Correspondence: adibsaad52@gmail.com

${ }^{1}$ Marine Science Laboratory, Faculty of Agriculture, Tishreen University, P.O

Box 1408, Lattakia, Syria

Full list of author information is available at the end of the article
}

recorded Pomacanthus imperator for the first time in the Mediterranean Sea in Haifa coast.

\section{Materials and methods}

On 18 February 2018, a $218 \mathrm{~mm}$ standard length $(272 \mathrm{~mm}$ total length) weight $1349 \mathrm{~g}$ specimen of Pomacanthus imperator (Bloch, 1787) was caught by trap on a marine area with sandy bottom (of $15 \mathrm{~m}$ deep). This area was located very close to the commercial port of at Lattakia City $\left(35^{\circ} .61^{\prime} \mathrm{N}, 36^{\circ} .002^{\prime}\right.$ E) (Fig. 1).

The specimen was measured accurately to the nearest millimeter and weighed to the nearest gram. Morphometric measurements, including percentages of standard length (SL), and meristic counts were all measured and noted following Golani (2010). The specimen was preserved in $10 \%$ buffered formalin and deposited in the Ichthyological Collection of the Marine Sciences Laboratory, Agriculture Faculty at Tishreen University, Syria, under the catalogue number: 257-2018 MSL (Fig. 2).

\section{Results and discussion}

Description of specimen: the body is oval-shaped, deep (133 $\mathrm{mm} ; 61.0 \%$ of SL) and compressed. The head is relatively small $(56 \mathrm{~mm} ; 25.7 \%$ of SL) and slightly concave into the dorsal profile. The predorsal $(80 \mathrm{~mm} ; 36.7 \%)$, preanal $(154 \mathrm{~mm} ; 70.6 \%)$ and preventral $(83 \mathrm{~mm} ; 38.1 \%)$ of 


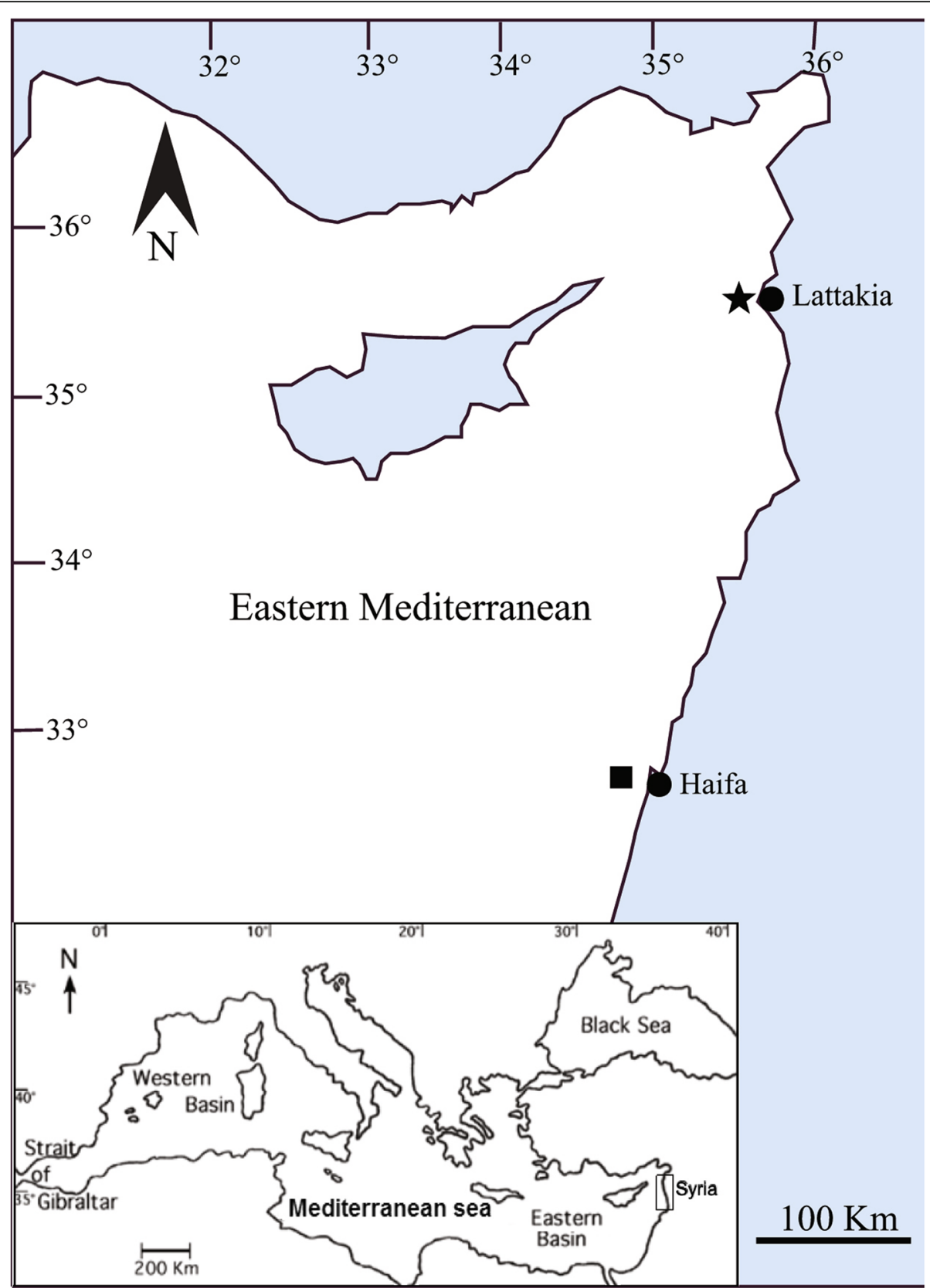

Fig. 1 Map of the Mediterranean and Levantine coast of Mediterranean pointing out the specimen collecting locality of Pomacanthus imperator; previous record (black square); present recorded (black star), and cities; Haifa and Lattakia (black circles)

standard length (SL. Small protractile and slanted mouth, its gape is close to half the distance of the vertical line of eye. Eyes are small $(7 \mathrm{~mm} ; 20.6 \%$ of head length) and has a wide interorbital (12 mm; 35.3\% of head length). Inside the mouth, aows of tightly-packed unicuspid depressible teeth are found forming a brush-like surface. The anterior teeth in both jaws are the longest, progressively decreasing in length when closing to the mouth opening and there are no teeth on the vomer or palatine. The gills are Short-raked, six are on the upper limb of the first arch and 13 on the lower limb and the posterior edge of preoperculum is finely serrated.

There is a long and stout spine at the lower angle of the preoperculum, its length is $41.0 \%$ relative to the head length. The dorsal fin is Continuous with 13 spines and 19 rays With clear incisions between the first spines progressively decrease toward the soft ray portion. Anal fin contains three spines with deep incisions between them and 19 rays. The posterior edge of the dorsal, anal and caudal fins are rounded while the Pectoral fin is 


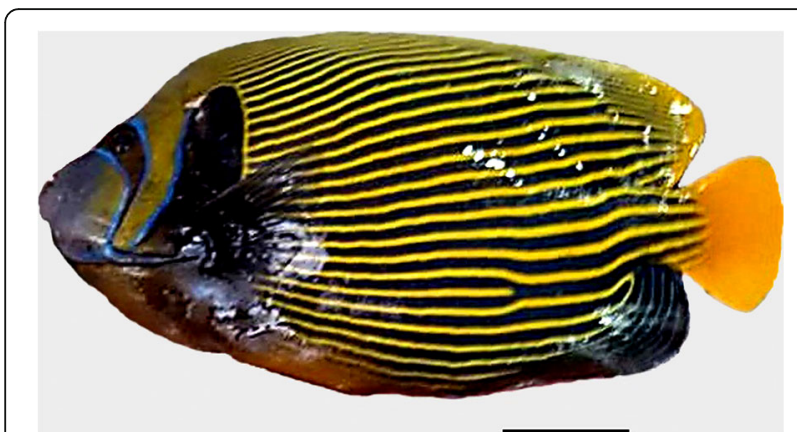

Fig. 2 The specimen of Pomacanthus imperator from Lattakia coast, scale bar: $50 \mathrm{~mm}$

supported by 19 rays in which the upper 2nd and 3rd are the longest. The pelvic fin contains one spine and five rays, the first ray is elongated.

The Body and head are covered with small ctenoid scales extending to the membrane of the median and pectoral fins. The colour of specimen (after being frozen for 2 days): Body and most of the dorsal fin are with slightly diagonal alternating stripes of yellow and grey-purple, the yellow strips are much narrower. The forehead is greenish-grey with light blue margin extending to the preopercular spine base. There is also the knownblack mask with bluish margin that covers the eye. In the rear of head and chest there is a dark (almost black) coloration and the snout and cheeks are pale grey. The anal fin is brown-reddish with curved blue stripes, thecaudal fin is yellow, the pectoral is dark grey to black while the pelvic fin ad bluish-grey membrane and orange rays.

\section{Origin and geographical distribution}

Pomacanthus imperator has a wide Indo-Pacific distribution from the Red Sea and eastern Africa to Japan, its type locality, and Tuamoto Island and a single record from Hawaii (Randall 2007). The Emperor Angelfish inhabit outer coral reef or rocky habitat at depths of 5-60 m. They live solitary or in pairs, the male defending aggressively its territory against cospecific males. Young specimens, up to $14 \mathrm{~cm}$, have distinctly different color pattern of deep blue with white and blue stripes on the anterior part of the body, curving progressively and forming circles on the posterior part of the body (Fricke 1980; Heemstra and Heemstra 2004). This pattern enables the juvenile to avoid male aggression and settle in either reef or rocky habitat (Fricke 1980). The source of this specimen could be a possible escapee from an aquarium, since $P$. imperator is a popular species in the aquarium trade. Alternatively, it could be a Lessepsian immigant that reached the eastern Mediterranean from the Red Sea via the Suez Canal. In 2009, Golani (2010) recorded Pomacanthus imperator for the first time in the Mediterranean Sea in Haifa coast (eastern Mediterranean) (Fig. 1). The record represents the second sighting of this species in the Levantine basin, but since it is based on a single isolated individual there is no evidence that the species has established a population in Syrian waters. Therefore at present $P$. imperator must be regarded as a casual species. There are other cases of Lessepsian immigrants such as Pterois miles, Parupeneus forsskali and Champsodon nudivittis reported by Ali et al. (2016a, 2016b, 2017), respectively were recorded recently in the Syrian coast.

\section{Conclusion}

The presently reported capture of Emperor angelfish Pomacanthus imperator (Bloch, 1787) from the Syrian coast would indicate that the species might be ventureing and expanding forther in the Mediterranean to reach new areas. This specimen is perhaps the documented case for this species after it was first observed in Haifa. Consequently, this sighting should be considered as the northernmost record made along the eastern Mediterranean coasts to date..

\section{Abbreviations}

E: East; N: North; SL: Standard length; TL: Total length

\section{Acknowledgements}

The authors would like to thank the Scientific and Technical Research Support Fund in the Syrian Ministry of Higher Education for providing material support to implement this research. We thank Dr. Ibrahem Ben Amer from RAC/SPA for reviewing the English language of the manuscript.

\section{Funding}

Scientific and Technical Research Support Fund in the Syrian Ministry of Higher Education.

Availability of data and materials

The specimen is available at Marine Science Laboratory-Tishreen university-LattakiaSyria. M.S.L 257-2018.

\section{Authors' contributions}

AS examined specimens, AS, HA and WS drafted the manuscript. All authors gave the final approval for publication.

Ethics approval and consent to participate

No ethical approval or consent to participate was required.

Consent for publication

Not applicable.

Competing interests

The authors declare that they have no competing interests.

\section{Publisher's Note}

Springer Nature remains neutral with regard to jurisdictional claims in published maps and institutional affiliations.

\section{Author details}

${ }^{1}$ Marine Science Laboratory, Faculty of Agriculture, Tishreen University, P.O Box 1408, Lattakia, Syria. ²Department of Biology, Faculty of sciences, Tishreen University, Lattakia, Syria. 
Received: 22 April 2018 Accepted: 3 July 2018

Published online: 13 July 2018

\section{References}

Ali M, Alkusairy H, Saad A, Reynaud C, Capapé C. Confirmed occurrence of common lionfish, Pterois miles (Osteichthyes: Scorpaenidae) in the eastern Mediterranean, with first record off the Syrian coast. Tishreen Univ J Res Sci Stud Biol Sci Ser. 2016a;38:307-13.

Ali M, Diatta Y, Alkusairy H, Saad A, Capapé C. First record of Red Sea goatfish Parupeneus forsskali (Osteichthyes: Mullidae) from the Syrian coast (eastern Mediterranean). J Ichthyol. 2016b;56:616-9.

Ali M, Saad A, Jabour R, Rafrafi-Nouira S, Capapé C. First record of nakedband gaper Champsodon nudivittis (Osteichthyes: Champsodontidae) off the Syrian coast (eastern Mediterranean). J Ichthyol. 2017;57:161-3.

Fricke HW. Juvenile-adult colour pattern and coexistence in the territorial coral reef fish Pomacanthus Imperator. Mar Ecol. 1980;1:133-41. https://doi.org/10. 1111/j.1439-0485.1980.tb00215.x.

Gerovasileiou V, Voultsiadou E, Issaris Y, Zenetos A. Alien biodiversity in Mediterranean marine caves. Mar Ecol. 2016; https:/doi.org/10.1111/maec.12268.

Golani D. Colonization of the Mediterranean by Red Sea fishes via the Suez Cana I Lessepsian migration. In: Golani D, Appelbaum-Golani B, editors. Fish invasions of the Mediterranean: change and renewal. Sofia: Pensoft; 2010. p. 145-88.

Heemstra P, Heemstra E. South African Institute for Aquatic Biodiversity and National Inquiry Service Centre. Grahamstown: Coastal Fishes of South Africa; 2004.

Nelson JS. Fishes of the world. 4th ed. New York: Wiley; 2006.

Por FD. Lessepsian migrat ion: the influx of Red Sea biota into the Mediterranean by way of the Suez Canal. Ecological studies, vol. 23. Berlin: Springer-Verlag; 1978. p. 228.

Randall JE. Reef and shore fishes of the Hawaiian islands. Honolulu: University of Hawai'i Press; 2007. p. 546

Saad A. Check - list of marine bony fish in Syria. Turk J Fish Aquat Sci. 2005;5:99-106.

\section{Ready to submit your research? Choose BMC and benefit from:}

- fast, convenient online submission

- thorough peer review by experienced researchers in your field

- rapid publication on acceptance

- support for research data, including large and complex data types

- gold Open Access which fosters wider collaboration and increased citations

- maximum visibility for your research: over $100 \mathrm{M}$ website views per year

At BMC, research is always in progress.

Learn more biomedcentral.com/submissions 